DOI: https://doi.org/10.47405/mjssh.v6i8.966

\begin{tabular}{|c|c|}
\hline 4 & Malaysian Journal of Social Sciences and Humanities (MJSSH) \\
\hline $\begin{array}{l}\text { Malaysian Juoural of } \\
\text { Social ccciecces and }\end{array}$ & Volume 6, Issue 8, August 2021 \\
\hline (MJ-sSH) & e-ISSN : 2504-8562 \\
\hline & $\begin{array}{l}\text { Journal home page: } \\
\text { www.msocialsciences.com }\end{array}$ \\
\hline
\end{tabular}

\title{
Intention to Choose Syariah Compliant Hospital: The Role of Religiosity
}

\author{
Hamidah Mat' ${ }^{1}$, Wan Mohd Al Faizee Wan Ab Rahaman¹, Norazzila Shafie ${ }^{1}$, Syed Tahir Syed \\ Mohamed ${ }^{1}$ \\ ${ }^{1}$ Kluster Pendidikan dan Sains Sosial, Open University Malaysia (OUM)
}

Correspondence: Hamidah Mat (hamidah@oum.edu.my)

\begin{abstract}
Syariah Compliant Healthcare Services in a rather unique trend that emerged in Malaysia. It started in few decades ago when certain 'Islamic' hospitals started offering Syariah compliant services with the tag line "Ibadah Friendly Hospital". Syariah Hospital of Islamic Hospital defined as hospital that provides health services in accordance with Syariah principles or in other words applying maqasid Syariah in hospital governance hospital. But a question remains, is there a necessity of Syariah compliant hospitals? And why it became a choice in the market. The research methodology used is qualitative based on content analysis technique to obtain data. This study seeks to find out the reason that motivates this choice by looking into the role of religiosity that is presumed to be the main reason for the choice. Based on the theory of reason action, a literature has been reviewed to construct tools to investigate Muslim attitude towards their intention to choose Syariah compliant hospital.
\end{abstract}

Keywords: hospital, syariah compliance, theory of reason action, maqasid syariah, religiousty

\section{Introduction}

The increased awareness of consuming only halal products and experiencing Halal services among Muslim consumers has influenced them to also seek for Syariah compliant healthcare services (Shaharom et al., 2018). The Development of Syariah Compliant Healthcare Services in Malaysia has started when a few hospitals offered Syariah compliant services with the tag line "Ibadah Friendly Hospital". Syariah Compliance Hospital $(\mathrm{SCH})$ is a hospital that provides health services in accordance with Syariah principles or in other words applying maqasid Syariah in hospital governance hospital (Moh. Abdurrokhman \& Wachyu Sulistiadi t.th.).

Amongst the earliest hospitals to introduce Syariah compliant healthcare services was the al-Islam Specialist Hospital in Kampung Baru which opened their services to the public in 2006 and was officially launched by the Ministry of Health in August 2010. It must be mentioned that the Pusat Rawatan Islam or PUSRAWI had also been introduced earlier than Hospital al-Islam in 1984. However, its establishment was not aimed to provide Syariah compliant healthcare services in its totality. Instead, it was a hospital that provided medical services for the public at large which is fully owned by the Majlis Agama Islam Wilayah Persekutuan. Nevertheless, one of its objectives is to inculcate Islamic principles as a work ethics Initially, the prime objective of the hospital was to provide the best services and facilities to help patients and at the same time also provide staff and patients as well as visitors with enough facilities to perform their Ibadah especially prayers (Syed Tahir, 2020). 
In general, these hospitals are expected to fulfil the needs of Muslims wishing to be treated according to Islamic principles especially when they are sick. This creates an awareness among patients and their families of the need to care for each other (hablu min an-nass) whilst observing compliant to syariah principles (Syed Tahir, 2020).

Subsequently, many other healthcare establishments followed suit. The Islamic Hospital Consortium was established in 2005 with an objective to establish contact and cooperation among its members in the field of healthcare services, strengthen ethical medical practice and hospital administration based on the principles of Islam (IHC, 2016). The Consortium also caters to both to the human capital as well as and services offered by member hospitals and ensures that these hospitals are syariah compliant in both aspects. This has also been adopted by some government hospitals such as in Sultan Abdul Halim Hospital and Selayang Hospital (Shariff et al., 2018).

Is there a necessity of syariah compliant hospitals? Muslims are obliged to observe the syariah in all aspects of their lives. Therefore, Syariah Compliant Hospital (SCH) services is designed to provide Muslim patients with services that abides by Islamic principles. There is high demand from Muslim consumers for quality health products because adhere to syariah principles (al-Harran \& Low, 2008). Moreover, Malaysia also has a strong reputation in the world in terms of medical travel destination after the International Medical Travel Journal (IMTJ) naming Malaysia as "Medical Travel Destination of the Year" because it has become the choice of middle eastern tourists and due to the position of halal goods (Rizqon et al., 2020).

The investigation of Muslim attitude towards SCH is important in Islamic societies such as Malaysia, where it is a number of research have done about this particular area. Nonetheless, the growing of many others private hospitals has shifted the perception of blind trust to various degrees of scepticism towards these brands in our societies. A strong and positive attitude towards SCH and its subsequent effect on intention to choose $\mathrm{SCH}$ will highlight the importance of properly addressing this issue in our country.

Thus, this study will explain the concept of SCH and the need in the society as well as the role of religiosity will be identified as a role of choosing SCH among the Muslims.

\section{Literature Review}

\section{The Concept of Syariah Compliant Hospital}

The concept of syariah compliant hospital can be defined as healthcare services offered by healthcare institutions which cater to the needs of Muslim patients while fulfilling specific requirements of the syariah. In shorts, the establishment of the institution must be aligned with maqasid al-syariah as it's the objectives. Thus, syariah compliant hospital should has its own characters distinguishes its identity from other hospitals (Moh. Abdurrokhman \& Wachyu Sulistiadi t.th).

Omar Hasan (2011) writes about the concept of a hospital in Islam. According to the author, a hospital in Islam must fully operate according to Islamic principles and must provide holistic care to all its patients. It must abide by the syariah principles, operate with quality utilizing modern and scientific medical techniques, however not forgetting also Islamic spiritual techniques for patients's recovery. What attracts the interest of the researcher is the statement made by the author that a hospital in Islam must not be misunderstood as a welfare organization. This is indeed important for the maintenance and survival of the hospital. Omar Hasan Kasule (2013) listed four basic guiding paradigms that must be taken into consideration in planning the establishment of a syariah compliant hospital. These guidelines are Integration (deriving from tauhid), Balance (tawāzun), Quality (ihsān and itqān) and Justice ( $\left.{ }^{\mathrm{c}} a d l\right)$. The author also stressed that a syariah compliant hospital must fulfil five principles of protection and preservation as underlined in maqasid Syariah; i.e. preservation of din (hifzal-dinn), life (hifz al-nafs), progeny (hifzal nasb), human intellect (hifz al ${ }^{c} a q l$ ) and resources (hifz al maāl). These are the basic principles in the establishment of a syariah compliant hospital. 
Omar Kasule (2013) also mentioned that the establishment of a syariah compliant hospital must undergo an evolutionary process rather a revolutionary. The author writes;

Implementation of a syariah compliant hospital will fail if initiated in a revolutionary way. The process should be evolutionary starting with what exists, making changes as we go along, and learning from experiences both positive and negative. The most strategic move in the whole process is the Islamic training of the professionals and workers in the hospital.

The view of the author is in line what the researcher has while in the process of conducting this research. It is important for a hospital in Islam to go through the process of becoming an ibadah friendly hospital before becoming a syariah compliant hospital. Positive and negative experiences in the early processes will develop maturity thus facilitate the implementation of the syariah compliant hospital.

Aomarun (2014) in his writing gave a comprehensive picture of a syariah compliant hotel;

The results of the literature review and related research found that features of Syariah Compliant hotel consists of 16 features as follows: No alcohol, Halal food only, Conservative television Service, Majority of staff of Muslim faith, Quran \& Prayer mats available in each room, Separate recreational facilities for men \& women, Makers in the rooms indicating the direction of Mecca, No entertainment such as night club, Bed \& Toilet should not be placed to face the direction of Mecca, Art in the hotel should not depict the human form, Bidets in the bathrooms, Appropriate entertainment, Hotel financed through Islamic Financial arrangement and Hotel should follow the Zakat principles. (Giving back to the community).

Although the author focused his discussion on the concept of a syariah compliant hotel, the researcher is of the opinion that the ideas above are very much related to services and requirements needed by a syariah compliant hospital.

Shaharom (2020) has proposed that the criteria for SCH can be categorize into four major components; infrastructure and facilities, personnel and staff development, procedures and workflow, system and technology. All these components have to be compliant with the Malaysian Private Healthcare Laws and Regulation Act 1998.

In hospital environment, the core services are related to clinical and nursing whereas the support services are those related to nonclinical for example account and finance, facilities management, IT systems and others. Syariah compliant hospital needs to provide facilities which includes accommodation as well as other facilities that assist the staff and patients to perform their daily ibadah, having a panel of expert to advice the hospital management on syariah compliant, and having a regular assessment including clients feedback to ensure syariah compliant.

In relation to the management of syariah compliant hospitals, (opines that the broad guidelines include a quality hospital management process together with an Islamic financial management system. Other than that, the management responsibilities cover the care of hospital facilities, patient care, customer service, human resource and the management of $F \& B$ as well as drugs administration, all of which must be in line with the syariah. In addition, the management of syariah compliant hospitals also needs to meet the standards stipulated under the Malaysian Standard MS 1900:2014 which provides guidelines for a Syariah-based quality management system (Syed Tahir, 2020).

In relation to services, the core services offered by the hospital would include the responsibility of physicians to provide sincere and genuine medical diagnosis, treatment and care to the patients with the aim of saving their lives. The physicians must make every effort to ensure that they perform their duties according to Islamic medical ethical principles so that they avoid any negligence which may harm a patient's life or cause injury. Aside from that, all procedures especially nursing procedures, 
(SOP) must incorporate syariah needs, having guidelines to handle Muslim and other patients and having trained staff to advise Muslim patients regarding ibadah and ruksah (an exception to a general law, granted to preserve life or remove hardship).

In terms of products, the Syariah compliant hospital needs to ensure two main types of products offered to their patients are in compliant to syariah principles and are halal and good (tayyiban) for their use and consumption. These are related to patient's dietary needs, personal and sanitary care and also food and beverages offered to the staff and visitors at the hospital. The second concern would of course be the medicine that is provided by the physicians in their attempt to cure the disease. The management of the syariah compliant hospital would have to ensure that the pharmaceutical products supplied to the patients comply to the strict halal requirements and are safe for Muslim consumption. There may be some concessions made in cases of dharurah or extreme necessity where non-halal pharmaceuticals may be resorted to if there are no other options available and to refrain from taking these medicines would result in the death of the patient. Other medical treatment related to protection of intellect is the necessity to ensure that the pharmaceutical products are halal and free from harmful ingredients. However, if alcohol is used as a solvent in medicine it is then permissible in Islam.

In relation to personnel and staff development, the component covers both the clinical and non-clinical staff. Although all staff is qualified to perform procedures according to their various disciplines, they are to be trained to understand essential syariah requirement before they are put to work. This includes a basic understanding of maqasid syariah, Islamic values, fiqh ibadah, fiqh muamalat and fiqh medic. Furthermore, Kasule (2013) also emphasize on observation of individual medical ethics which are morally in line with syariah practices.

Based on the literature, Shariff et al. (2018) has proposed a SCH Framework for Malaysia based on MS 1900:2014. The core principles of the framework remain 4 major items. These four items will be the impetus for the other pillars since they form the base for the other four pillars. The four pillars are private healthcare facilities and Services Act 1998, maqasid syariah (objectives of the syariah), operation based on value system and compliants with the principles of halal and haram.

Therefore, as proposed Majdah and Khadijah (2017) by the whole "eco-system" of the hospital must be syariah compliant. This means that the management, services, products and facilities offered must all comply to syariah principles.

Based on SIRIM's Syariah based quality management system framework, the application of syariah standards in the quality management system has an outcome in the form of customer satisfaction. The application of framework in hospitals is expected to increase patient satisfaction (Shariff \& Mohtar, 2016). Therefore, SIRIM (Standard and Industrial Research Institute of Malaysia), the company appointed by the Malaysian standards department to develop, accredit and certify standards, has developed a syariah quality management system in general (MS 1900: 2014) which provides guidance for all organizations wishing to implement sharia-based quality management systems (Shariff \& Mohtar, 2016). If the application of Syariah standard has increase the quality of health care and patient's satisfaction, then the Syariah standard should be the way forward for health care provider in the country.

\section{Methodology}

This study applied qualitative method based on content analysis technique to obtain data. The study has reviewed comprehensive articles related to concept of shariah compliance, hospitals and services provided to society in scholarly journals. In addition, the study also reviewed several theories and theory of reason action (TRA) has been chosen and founded that religiosity as a construct that related to the study. 


\section{Result and Discussion}

Based on the discussion, theory of reason action (TRA) was designed to take account of people decision-making (Ajzen \& Fishbein 1980). The TRA in order to establish links between beliefs, attitudes, intentions and behaviours (Md-Taib et al., 2008). Most human behaviours are predictable based on intention because such behaviours are volitional and under the control of intention (Ajzen \& Fishbein, 1980). TRA posits that individual behaviour is driven by behavioural intentions where behavioural intentions are a function of an individual's attitude toward the behaviour and subjective norms surrounding the performance of the behaviour. The TRA proposes that a person's objective and intent to purchase a product is based on two core aspects, one is the personal in nature and second is the reflection of social influence (Lada et al., 2009).

TRA consider both social (subjective norm) and psychological (attitudes) factors in consumers decision-making process and have been accepted and utilized to predict individual's behaviors. TRA is the most relevant theoretical model in context of SCH. First' it explicitly embeds subjective norms in attitude formation process (Ajzen \& Fishbein, 1980). Subjective norms are individual beliefs about what other people think she or her should do in a certain context but give less attention to the concept of personal norms (i.e., individual beliefs or perceptions of right or wrong). Attitude is an individual feeling to perform certain behaviors that are beneficial and unfavourable (Fishbein 2008). It not only measures the individual attitude towards an object but also accounts for the role of reference groups in forming and reinforcing such attitudes (Lada et al., 2009; Lutz, 1991). An individual behavioural intention is a combination of attitudes toward behaviour and subjective norms. TRA is one's own perception of the social pressures to behave or not, in a particular manner (Ajzen \& Fishbein, 1980; Lada et al., 2009). The behavioural beliefs, i.e. the act of consuming or choose Syariah Compliant service, are the beliefs that motivate a person's attitude towards behaviour.

This study does not require subjective attitudes while the subjective norm is religiosity. Thus, the present study extends the theory (TRA) to the context of choosing Syariah compliant hospital by integrating religious commitment into TRA in order to get better prediction towards the behavioural intention to choose the hospital. It will be interesting to investigate which component of religiosity better predicts consumer intention to choose Syariah compliant hospital.

\section{Religiosity}

Religiosity is the extent to which an individual is committed to his religion, reflected in his/her attitudes and behaviour (Johnson, 2001). Based on the theory of reason action, the construct is used to investigate Muslim attitude towards their intention to choose Syariah compliant hospital.

Religion persuades people's goals, decisions, motivations, purpose and satisfaction. It is regarded as a system of beliefs and practices that dictates individual response and interpretations regarding what is supernatural and sacred. However, few argue that religious beliefs are tangled with cognitive elements, providing the basis of knowledge that control and justify our attitudes and behaviour (Foxall \& Goldsmith, 1994). This influence also plays a dominant role in shaping individual's attitude and behaviour towards material goods and services (Fam et al., 2004).

Therefore, religion in general and Islam in particular, being an integral part of culture influences market researchers, to explore its role in the consumption world. Hence it is important for organizations to investigate, understand and gauge the role of religion in purchasing decision of its intended segment. This will enable organizations to develop products that conform to the religious requirements of its customers (Mukhtar \& Butt, 2012).

Religiosity was thought to be a single dimensional construct measured only by a person's attendance to a religious centre and his/her contribution to that sect. Religiosity has two elements; intrinsic religiosity which explains religion as framework to understand life; and extrinsic religiosity which is a social convention (Mokhlis, 2009). 
While others suggested a tri-component (cognitive, behavioural, experimental) model of religiosity: cognitive component describes religious attitudes or beliefs, the behavioural component addresses a person's religious institutional attendance and prayers and the experimental that addresses the need of mystical experiences (Ramly et al., 2008). Previously, Worthington et al. (2003) has suggested a twofactor solution, one reflects the cognitive (intra-personal) dimension of religious beliefs and the other focuses on the behavioural (inter-personal) dimension by measuring individual participation in organized religious activities.

Researchers have argued that the effect of religion on consumer behaviour depends on the level of individual religious commitment in his personal life because religion is basically very personal (Mokhlis, 2009). Houck et al. (2018) wrote that religion tends to cause complexity because the nature of a religious system (the questions they face) is often complex, whereas, on the other hand, religion also able to create an easy way of thinking.

Religiosity reflects what extent beliefs in religious values and ideals are held and practiced by an individual. This indicates that religion has a role in shaping the need for consumption in Muslim countries (Shabbir, 2010). Therefore, Alserhan (2010) emphasized that characteristics of Muslim consumers depend on religious values while the characteristics of purchases depend on their religious beliefs in his discussion regarding Islamic branding. A study conducted by Fauzi et al. (2016) revealed that religiosity affects Muslim consumers to shop. Muslim consumers will develop better attitudes and motivations to visit stores with products that are similar to the value they hold. He concluded that the more religious Muslim consumers, the more they become obedient to religion and look at the store not only to meet certain consumption needs but also religious motives.

In conjunction with the religiosity as a factor in choosing product or services, subjective norms identified influencing such attitudes and intention to choose Syariah Compliant Hospital can help in explaining the role of reference groups in particular and society in general in forming such attitudes (Ajzen \& Fishbein 1980). Subjective norms refer to the belief that an important person or group of people will approve and support a particular behaviour. Subjective norms are determined by the perceived social pressure from others for an individual to behave in a certain manner and their motivation to comply with those people's views. The influence of subjective norms on forming intention proved to be generally weaker in previous studies than the influence of attitude. Rivis and Sheeran (2003) argue that the confirmed correlation between descriptive norms and intentions implies the possibility of the predictive power of this variable, which gives a strong motivation for further research in this area.

Descriptive norms refer to real activities and behaviours that others are undertaking. In contrast, social norms refer to the perception of other people's opinions on how the individual should behave. We consider both of these variables (descriptive and social norms) to be a part of the subjective norms factor.

Based on the analysis of the construct of religiousity from the theory of reason action(TRA) and the concept of Shariah compliance, the study found that the element of religioustiy is an important element in determining the tendency towards the selection of Shariah -compliant hospitals. This element is seen to influence propensity and can be measured via the RC-10 method. The combination between these techniques and elements is believed to be strengthened through more in -depth studies in the future.

\section{Conclusion}

Researchers have argued that the effect of religion on consumer behaviour depends on the level of individual religious commitment in his personal life because religion is basically very personal. However, this study supposes that Religiosity has a role in shaping the need for consumption in Muslim countries due to myriad of studies done on it. Previous studies also show that Muslim consumers depend on religious values in their economic consumption. In conjunction with the 
religiosity as a factor in choosing product or services, subjective norms identified influencing such attitudes and intention to choose Syariah Compliant Hospital can help in explaining the role of reference groups in particular and society in general in forming such attitudes with the presumption that the correlation between descriptive norms and intentions implies the possibility of the predictive power of this variable, which gives a strong motivation for further research in this area. While the theory of reason action (TRA) that was designed to take account of people decision-making in order to establish links between beliefs, attitudes, intentions and behaviours has been identified as a suggested theoretical framework to investigate the relationship between religiosity and the intention to choose a Sharia Compliant Hospital. This study also proposed a further study using semi-structured interview for a selected group of Muslim based on religiosity stages.

\section{Acknowledgement}

This paper is one of the research results for the Internal Research Fund (IRF) of Open University Maaysia (OUM) under the project entitled, 'Perception of OUM Staff towards the Practicality of Shariah Compliant Hospital in Malaysia’ numbered OUM-IRF-2021-002.

\section{References}

Abdurrokhman, M., \& Sulistiadi, W. (2019). Sharia hospital as an added value: a systematic review. In 6th International Conference on Public Health 2019 (pp. 413-418).

Ajzen, I. (1988). Attitudes, Personality, and Behavior. Chicago: Dorsey Press.

Ajzen, I. (1991). The theory of planned behavior. Organizational Behavior and Human Decision Processes. 50, 179-211.

Ajzen, I. \& Fishbein, M. (1980). Understanding Attitudes and Predicting Social Behaviour. PrenticeHall: Englewood Cliffs, NJ.

Al-Harran, S., \& Low, K. C. P. (2008). Marketing of halal products: the way forward. The Halal Journal, 44-46.

Allport, G. \& Ross, J. (1967). Personal religious orientation and prejudice. Journal of Personality and Social Psychology, 5(4), 432-43.

Allport, G. (1950). The Individual and His Religion: A Psychological Interpretation. New York, NY: Macmillan.

Alserhan, B. A. (2010). On Islamic branding: brands as good deeds. Journal of Islamic Marketing.

Alserhan, Fishbein, M., \& Ajzen, I. (1975). Belief, Attitude, Intentions and Behavior: An Introduction to Theory and Research. Addison-Wesley.

Aomarun, J. (2014). The attribution of syariah compliant hotel in muslim countries. Rev. Integr. Bus. Econ. Res., 3, 39-44.

Bryman, A. (2004). Social Research Methods. Oxford University Press: New York.

Fam, K. S., Waller, D. S., \& Erdogan, B. Z. (2004). The influence of religion on attitudes towards the advertising of controversial products. European Journal of Marketing.

Fauzi, W. I. M., Muhammad, N., Mokhtar, S. S. M., \& Yusoff, R. Z. (2016). What motivate Muslim consumer to patronage Islamic based-retail store?. International Review of Management and Marketing, 6(7S).

Fishbein, M. A. (2008). A reasoned action approach to health pro-motion. Medical Decision Making. $28,834-844$.

Foxall, G. R. (1994). Behavior analysis and consumer psychology. Journal of Economic Psychology, 15(1), 5-91.

Gaur, S. S., Xu, Y., Quazi, A., \& Nandi, S. (2011). Relational impact of service providers' interaction behavior in healthcare. Managing Service Quality: An International Journal, 21(1), 67-87.

Houck, S. C., Conway III, L. G., Parrow, K., Luce, A., \& Salvati, J. M. (2018). An integrative complexity analysis of religious and irreligious thinking. SAGE Open, $8(3)$. 
Johnson, B. R., Jang, S. J., Larson, D. B., \& De Li, S. (2001). Does adolescent religious commitment matter? A reexamination of the effects of religiosity on delinquency. Journal of Research in Crime and Delinquency, 38(1), 22-44.

Johnstone, R. L. (1975). Religion and Society in Interaction. Prentice-Hall.

Lada, S., Tanakinjal, G.H. and Amin, H. (2009). Predicting intention to choose Halal products using theory of reasoned action. International Journal of Islamic and Middle Eastern Finance and Management, 2(1), 66-76.

Lung, C.K., Chai, L.T. \& Zulkufly, R. (2008). Religiosity as a predictor of consumer ethical behaviour: a comparative study between public and private university students in Malaysia. Journal of Business Systems, Governance and Ethics, 3, 43-56.

Lutz, R. (1991). The role of attitude theory in marketing, in Kassarjian, H.A. (pnyt.) Perspectives in Consumer Behaviour. Prentice-Hall: Englewood Cliffs, NJ.

Majdah, Z \& Khadijah, O. (2017). An overview of syariah compliant healthcare services in Malaysia. Malaysian Journal of Consumer and Family Economics, 20(S 1), 91-100.

Md-Taib, F., Ramayah, T. \& Abdul-Razak, D. (2008). Factors influencing intention to use diminishing partnership home financing. International Journal of Islamic and Middle Eastern Finance and Management, 3(1), 235-248

Mokhlis, S. (2006). The effects of religiosity on shopping orien-tations: an exploratory study in Malaysia. Journal of the American Academy of Business, 9(1), 64-74.

Mokhlis, S. (2009). Relevancy and measurement of religiosity in consumer behaviour research. International Business Research, 2(39), 75-84.

Mokhlis, S. (2009). Relevancy and measurement of religiosity in consumer behavior research. International Business Research, 2(3), 75-84.

Mukhtar, A., \& Butt, M. M. (2012). Intention to choose halal products: the role of religiosity. Journal of Islamic Marketing.

Omar, H.K. (2011). Islamic Hospital Guidelines. Paper presented at 7th International Seminar \& Workshop Understanding Qur'anic Principles and Values in Healthcare, December 15th-17th, Kuala Lumpur, Malaysia

Omar, H. K. (2013). Toward syariah compliant hospital: planning, implementation and challenges. Presented at a Seminar on Islamization of the Medical 107 Curriculum and Practice at the International Islamic University Kuantan Malaysia 26th-27th August 2013.

Ramly, Z., Chai, L. T., \& Lung, C. K. (2008). Religiosity as a predictor of consumer ethical behaviour: Some evidence from young consumers from Malaysia. Journal of Law and Governance, 3(4).

Razak, D. A., Mohammed, M. O., \& Taib, F. M. (2008). Consumers acceptance on Islamic home financing: empirical evidence on Bai Bithaman Ajil (BBA) in Malaysia. IIUM International Accounting Conference IV: 1-22.

Rivis, A., \& Sheeran, P. (2003). Descriptive norms as an additional predictor in the theory of planned behaviour: a meta-analysis. Current Psychology, 22(3), 218-233.

Rizqon, M. S., Sulisno, M., \& Suryawati, C. (2020). Sharia Services with A Level of Patient Satisfaction in Hospitals: Literature Review. Jurnal Keperawatan Respati Yogyakarta, 7(1), 27 31.

Shabbir, M. S. (2010). The relationship between religiosity and new product adoption. Journal of Islamic Marketing.

Syed Tahir. (2020). Persepsi badan pengurusan pusat perubatan universiti Islam antarabangsa Malaysia (ppuiam) Terhadap Kesediaan Pelaksanaan Hospital Patuh Syariah (Sharia Compliant Hospital). Tesis Master, Open University Malaysia. (Unpublished).

Shariff, S. M., Mohtar, S., \& Jamaludin, R. (2018). A practical journey in implementing a syariah compliant hospital: an nur specialist hospital's experience. IIUM Medical Journal Malaysia, $17(2)$.

Worthington Jr, E. L., Wade, N. G., Hight, T. L., Ripley, J. S., McCullough, M. E., Berry, J. W., \& O'Connor, L. 2003. The religious commitment inventory 10: development, refinement, and validation of a brief scale for research and counseling. Journal of Counseling Psychology, 50(1), 84. 